\title{
Langerhans cell histiocytosis of the rib presenting with pathological fracture: a case report
}

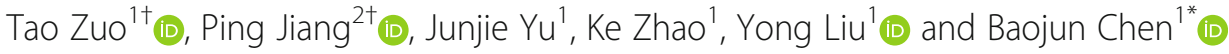

\begin{abstract}
Introduction: Langerhans cell histiocytosis $(\mathrm{LCH})$ is a rare neoplastic hyperplasia with an unknown etiology. It is clinically rare for patients with solitary rib lesion and pathological fracture; moreover, its diagnosis and treatment are quite difficult. The purpose of this study is to present a case for the pathogenesis, clinical features, imaging, and treatment of this disease.

Case presentation: A 52-year-old female patient complained of left chest pain for one week. CT showed a fracture in the left 5th rib. The rib tumor was then resected and the surrounding muscles and soft tissues were accordingly resected. The patient was diagnosed with pathological rib fracture, and the patient was pathologically diagnosed with LCH. After surgery, no local recurrence or distant metastasis was reported during the two-year follow-up.

Conclusions: LCH should be treated by observation, chemotherapy, radiotherapy, or surgery, or using a combination of several methods. Moreover, primary tumor should be considered when rib fracture without trauma and tumor metastasis.
\end{abstract}

Keywords: Langerhans cell Histiocytosis, Rib, Pathological fracture

\section{Introduction}

Langerhans cell histiocytosis (LCH), known as eosinophilic granuloma of bone, is a rare neoplastic hyperplasia having an unknown etiology. LCH is characterized by intense and abnormal proliferation of bone marrowderived histiocytes (Langerhans cells), leading to its high rate of misdiagnosis and missed diagnosis. $\mathrm{LCH}$ has a highly variable clinical presentation, ranging from a single lesion to potentially fatal disseminated disease. It is clinically rare for patients with solitary rib lesion and pathological fracture, and its diagnosis and treatment are

\footnotetext{
* Correspondence: zuotaowuhan@126.com

†Tao Zuo and Ping Jiang contributed equally to this work.

'Department of Thoracic Surgery, The Central Hospital of Wuhan, Tongji Medical College, Huazhong University of Science and Technology, Wuhan, China

Full list of author information is available at the end of the article
}

quite difficult. In this study, we report a patient with $\mathrm{LCH}$ presenting with pathological rib fracture.

\section{Case presentation}

A 52-year-old female patient complained of left chest pain for one week. The patient had no history of trauma or other diseases. Physical examination indicated slight tenderness in the left chest and normal breathing sounds in both lungs. Chest computed tomography (CT) conducted at the outpatient department indicated local bone density reduction along with fracture of the left 5 th rib and thickening of the soft tissue adjacent to the chest wall; the possibility of a pathological fracture could not be excluded (Fig. 1a). Thus, relevant examinations were performed. Bone scanning presented abnormal radioactive concentrations in the left 5th rib (Fig. 1b). No abnormalities were then revealed on the head magnetic resonance imaging (MRI) or color doppler ultrasound of

C The Author(s). 2020 Open Access This article is licensed under a Creative Commons Attribution 4.0 International License, which permits use, sharing, adaptation, distribution and reproduction in any medium or format, as long as you give appropriate credit to the original author(s) and the source, provide a link to the Creative Commons licence, and indicate if changes were made. The images or other third party material in this article are included in the article's Creative Commons licence, unless indicated otherwise in a credit line to the material. If material is not included in the article's Creative Commons licence and your intended use is not permitted by statutory regulation or exceeds the permitted use, you will need to obtain permission directly from the copyright holder. To view a copy of this licence, visit http://creativecommons.org/licenses/by/4.0/. The Creative Commons Public Domain Dedication waiver (http://creativecommons.org/publicdomain/zero/1.0/) applies to the data made available in this article, unless otherwise stated in a credit line to the data. 

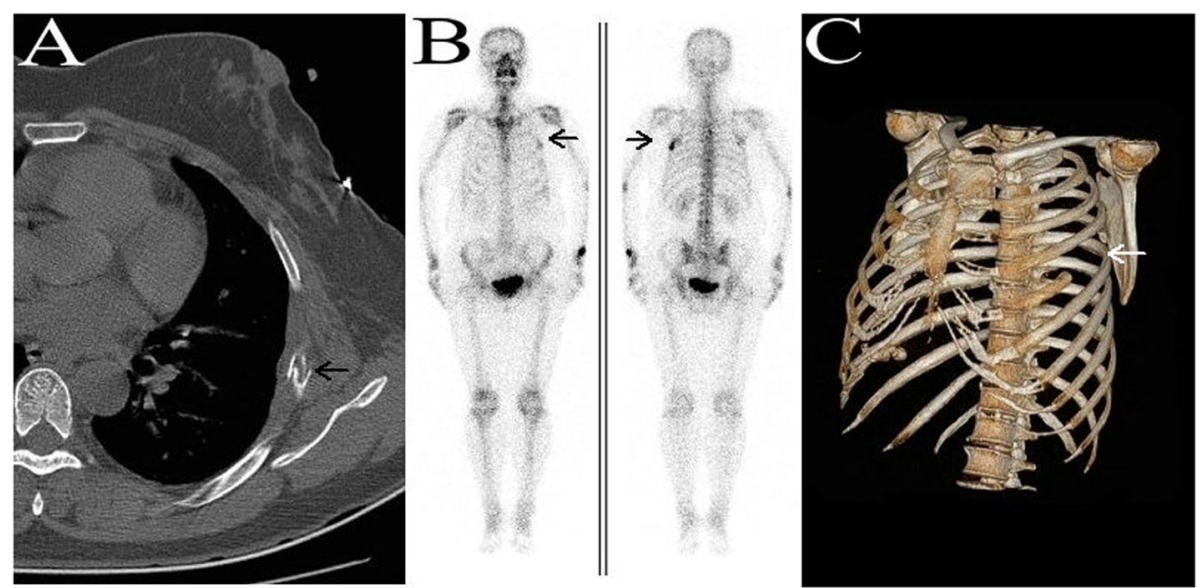

Fig. 1 a. Preoperative chest $C T$ suggests pathological fracture. b. Bone scanning suggests increased local metabolism of the lesion. $\mathbf{c}$. Postoperative $C T$ of chest wall reconstruction

the liver, gallbladder, pancreas, and spleen. The patient was diagnosed with a single rib lesion. Because of the reduced effect that surgical resection had on respiratory function, the rib tumor was resected and surrounding muscles and soft tissues were accordingly resected. Postoperative pathology indicated massive Langerhans cell infiltration (Fig. 2). Immunohistochemistry demonstrated CD1a (+) and S-100 (+) (Fig. 3). Therefore, the patient was diagnosed with $\mathrm{LCH}$; after surgery, no local recurrence or distant metastasis was reported during the two-year follow-up (Fig. 1c).

\section{Discussion}

$\mathrm{LCH}$ is a clonal proliferative disease caused by the proliferation and aggregation of Langerhans cells $\left(\mathrm{CD} 207^{+}\right)$ with abnormal function in single or whole-body tissues and organs [1]. I the general population, its incidence is estimated to be 1 or 2 cases per 1 million individuals, whereas incidence in children aged $1-3$ years is even higher at 3-5 cases per 1 million individuals $[2,3]$. $\mathrm{LCH}$ can involve a single organ, a single system and multiple organs, or multiple systems and multiple organs [4]. Its symptoms range from single self-absorbed organ hyperplasia (the mildest) to systemic infiltrative hyperplasia (the severest). The organs that are always involved include the bone, lung, central nervous system, liver, thymus, skin, and lymph nodes. As for bones, the skull, long bone, and flat bone are the most susceptible. The mortality rate of patients with multiorgan $\mathrm{LCH}$ is $10-20 \%$ [5]. The clinical manifestations of LCH are nonspecific, and this lack of specificity makes its diagnosis difficult. However, once $\mathrm{LCH}$ is considered as a possibility, the diagnosis can then be confirmed by biopsy. Pathology will show pathological Langerhans cells and mediated inflammatory cells, including lymphocytes, eosinophils, and macrophages. S-100 protein, CD1a, and CD207 in Langerhans cells are positive, whereas Birbeck granules under an electron microscope are specific $[6,7]$.

LCH can be treated by observation, chemotherapy, radiotherapy, or surgery, or using a combination of

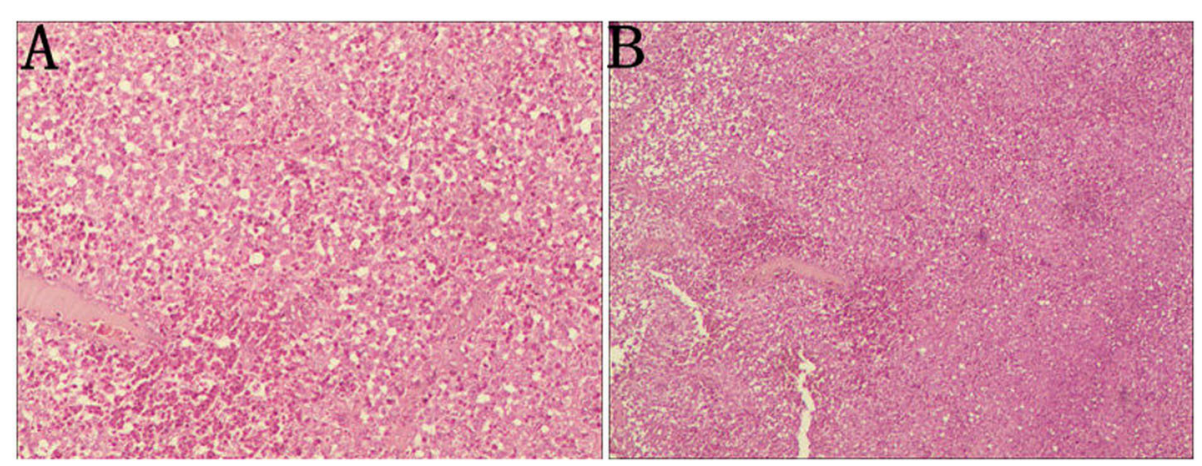

Fig. 2 Pathology shows Langerhans cells and mediated inflammatory cells, including lymphocytes, eosinophils and macrophages 


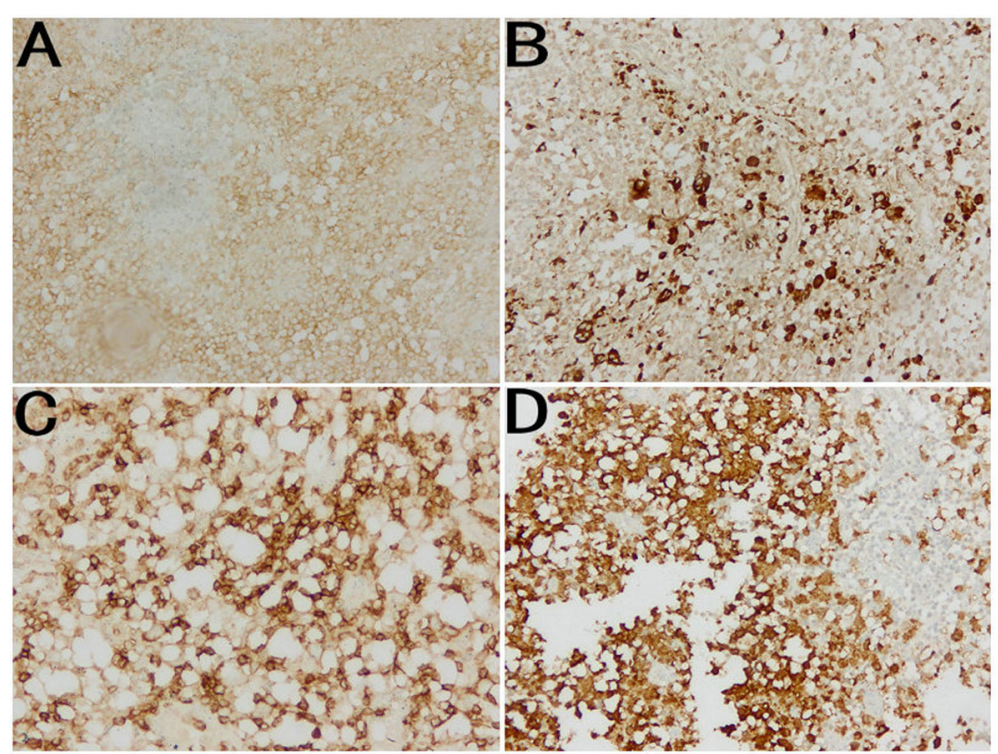

Fig. 3 Immunohistochemistry demonstrated CD1a (a),CD68 (b), LCA (c) and S-100 (d) are positive

several methods. Patients with good prognosis may only require follow-up observation or little intervention, whereas patients with poor prognosis should be actively treated. The long-term efficacy and prognosis still require further follow-up observation [8]. A study has demonstrated that only 2 of 61 patients with $\mathrm{LCH}$ of single bone had a recurrence after surgical resection [9]. Another study has demonstrated that the four-year survival rate of patients with $\mathrm{LCH}$ of single bone is $>90 \%$ [10]. Teratogenic surgery is not recommended for patients with a single small lesion because it is always self-limiting. In such cases, the local lesion of the rib is definitively diagnosed via surgical resection, whereas the resection has little effect on the patient's function. Similar to other benign tumors, surgical removal is effective in this case [11, 12]. Local radiotherapy of bone lesions is only suitable for patients with lesion progression, which may affect the function of important organs. Patients with systemic invasion should be actively treated using chemotherapy, whereas high-risk patients with multisystem diseases accompanied by organ dysfunction should be treated using systemic therapy along with chemotherapy.

Generally, among young adults, the skeletal loads causing rib fractures are attributed to high-energy traumatic events. In older adults, rib fractures often result from falls [13, 14]. Pathological rib fracture is a common manifestation of malignant tumor rib metastasis. In this study, primary tumor of ribs may lead to rib fracture.

\section{Conclusions}

In conclusion, we report a patient with $\mathrm{LCH}$ who presented with pathological rib fracture; for this case, surgical removal was effective. However, LCH should be treated by observation, chemotherapy, radiotherapy, or surgery, or using a combination of several methods. Furthermore, primary tumor should be considered when rib fracture without trauma and tumor metastasis.

\section{Acknowledgments}

No

\section{Authors' contributions}

$T Z, Y L, B C$ participated in the care of the patient.TZ and PJ performed the literature review and drafted the manuscript. TZ obtained the image data. All authors read and approved the final manuscript.

\section{Funding}

Health Commission of Hubei Province scientific research project (WJ2019M032).

\section{Availability of data and materials}

Not applicable.

Ethics approval and consent to participate

The ethics committee of The Central Hospital of Wuhan approved the study.

\section{Consent for publication}

The patient provided written informed consent.

All presentations of case reports have consent to publish.

\section{Competing interests}

The authors declare that they have no competing interests.

\section{Author details}

'Department of Thoracic Surgery, The Central Hospital of Wuhan, Tongji Medical College, Huazhong University of Science and Technology, Wuhan, China. ${ }^{2}$ Department of ophthalmology, Zhongnan Hospital of Wuhan University, Wuhan, China. 
Received: 18 June 2020 Accepted: 28 October 2020

Published online: 23 November 2020

References

1. Zinn DJ, Chakraborty R, Allen CE. Langerhans Cell Histiocytosis: Emerging Insights and Clinical Implications. Oncology (Williston Park, N.Y.). 2016;30(2): 122-32 139.

2. Arceci RJ. The histiocytoses: the fall of the Tower of Babel. Eur J Cancer. 1999:35:747-69.

3. Baumgartner I, von Hochstetter A, Baumert B, Luetolf U, Follath F. Langerhans'-cell histiocytosis in adults. Med Pediatr Oncol. 1997:28:9-14.

4. McClain KL, Natkunam Y, Swerdlow SH. Atypical cellular disorders. ASH Education Book. 2004;1:283-96.

5. Kim SH, Choi MY. Langerhans Cell Histiocytosis of the Rib in an Adult: A Case Report. Case Rep Oncol. 2016:9(1):83-8.

6. Favara BE, Feller AC, Pauli M, et al. Contemporary classification of histiocytic disorders. The WHO Committee on Histiocytic/Reticulum Cell Proliferations. Reclassification Working Group of the Histiocyte Society. Med Pediatr Oncol. 1997:29:157-66

7. Chikwava K, Jaffe R. Langerin (CD207) staining in normal pediatric tissues, reactive lymph nodes, and childhood histiocytic disorders. Pediatr Dev Pathol. 2004;7:607-14.

8. Suzuk i T, Izutsu K, Kako S, et al. A case of adult Langerhans cell histiocytosis showing successfully regenerated osseous tissue of the skull after chemotherapy. Int J Hemato. 2008;87(3):284.

9. Jubran RF, Marachelian A, Dorey F, Malogolowkin M. Predictors of outcome in children with Langerhans cell histiocytosis. Pediatr Blood Cancer. 2005;45: 37-42 11 Wester SM, Beabout JW.

10. Unni KK, Dahlin DC. Langerhans' cell granulomatosis (histiocytosis X) of bone in adults. Am J Surg Pathol. 1982;6:413-26.

11. Zuo T, Fu J, Ni Z, et al. Pulmonary inflammatory Myofibroblastic tumor indistinguishable from tuberculosis: a case report in a five-year-old child with hemoptysis. J Cardiothoracic Surg. 2017;12(1):112

12. Zuo T, Gong FY, Chen BJ, et al. Video-assisted thoracoscopic surgery for the treatment of mediastinal lymph node tuberculous abscesses. J. Huazhong Univ. Sci. Technol. Med. Sci. 2017;37:849-54.

13. Palvanen M, Kannus P, Niemi S, Parkkari J. Hospital-treated minimal-trauma rib fractures in elderly Finns: long-term trends and projections for the future. Osteoporosis Int. 2004;15(8):649-53.

14. Barrett-Connor E, Nielson CM, Orwoll E, Bauer DC, Cauley JA. Epidemiology of rib fractures in older men: Osteoporotic Fractures in Men (MrOS) prospective cohort study. Br Med J. 2010;340:C1069.

\section{Publisher's Note}

Springer Nature remains neutral with regard to jurisdictional claims in published maps and institutional affiliations.

Ready to submit your research? Choose BMC and benefit from:

- fast, convenient online submission

- thorough peer review by experienced researchers in your field

- rapid publication on acceptance

- support for research data, including large and complex data types

- gold Open Access which fosters wider collaboration and increased citations

- maximum visibility for your research: over $100 \mathrm{M}$ website views per year

At $\mathrm{BMC}$, research is always in progress.

Learn more biomedcentral.com/submissions 